\title{
Sebaran Horizontal Fosfat, Nitrat dan Oksigen Terlarut di Perairan Pantai Bolaang Mongondow, Sulawesi Utara
}

\section{Horizontal distribution of Phosphate, Nitrate and Dissolved Oxygen on the waters of Bolaang Mongondow Beach, North Sulawesi}

\author{
Simon I. Patty ${ }^{1}$ dan Nebuchadnezzar Akbar ${ }^{2}$ \\ ${ }^{1}$ Loka Konservasi Bita Laut Bitung-LIPI \\ ${ }^{2}$ Program Studi Ilmu Kelautan, FPIK, Universitas Khairun, Ternate \\ E-mail:pattysimon@ymail.com
}

\begin{abstract}
ABSTRAK
Pengamatan fosfat, nitrat dan oksigen terlarut telah dilakukan di perairan Bolaang Mongondow, Sulawesi Utara pada bulan Pebruari 2019. Tujuan penelitian ini untuk mengetahui kondisi perairan berdasarkan ketersediaan dan distribusi spasial fosfat, nitrat dan oksigen terlarut di perairan tersebut. Analisa fosfat dan nitrat berdasarkan metoda spektrofotometri menggunakan spektrofotometer UV-VIS Shimadzu 1700. Kadar oksigen terlarut ditentukan dengan metoda elektrokimia menggunakan DO meter AZ 8563. Hasil analisis statistik dengan menggunakan uji-t menunjukkan bahwa kadar fosfat dan oksigen terlarut di lapisan permukaan dengan dekat dasar adalah berbeda, sedangkan kadar nitrat tidak berbeda antara lapisan permukaan dengan dekat dasar. Tinggi rendahnya kosentrasi fosfat, nitrat dan oksigen terlarut di perairan ini dipengaruhi oleh arus, pergerakan massa air, aktifitas plankton dan masukkan dari daratan. Kadar fosfat, nitrat dan oksigen terlarut di perairan Bolaang Mongondow masih tergolong normal dan baik untuk kehidupan biota laut.
\end{abstract}

Kata kunci: Sebaran, fosfat, nitrat, oksigen terlarut, kualitas air, Sulawesi Utara

\section{ABSTRACT}

Observation of phosphate, nitrate and dissolved oxygen was carried out in Bolaang Mongondow, North Sulawesi in February 2019. This study aims to determine the condition of the waters based on the availability and spatial distribution of phosphates, nitrates and dissolved oxygen in these waters. Phosphate and nitrate analysis based on spectrophotometric methods using Shimadzu 1700 UV-VIS spectrophotometer. Dissolved oxygen levels were determined by electrochemical methods using DO meter AZ 8563. The results of statistical analysis using the t-test showed that phosphate levels and dissolved oxygen in the surface layer near the base were different, whereas nitrate levels do not differ between surface layers and near the base. High and low concentrations of phosphate, nitrate and dissolved oxygen in these waters are affected by flow, mass movement of water, plankton activity and inputs from land area. Phosphate, nitrate and dissolved oxygen levels in Bolaang Mongondow waters are still normal and good for the life of marine biota.

Keywords: Distribution, phosphate, nitrate, dissolved oxygen, water quality, North Sulawesi 


\section{Pendahuluan}

Perairan Bolaang Mongondow secara geografis masuk dalam wilayah laut Sulawesi. merupakan perairan pantai dan estuari yang sangat penting di bidang perikanan. Perairan ini tergolong memiliki ekosistem pesisir yang lengkap; mangrove, terumbu karang dan lamun yang sangat kaya dengan berbagai jenis biota laut, sehingga sering digunakan nelayan setempat sebagai daerah penangkapan ikan (fishing ground). Hal ini dapat dimengerti karena perairan tersebut kondisinya subur dan merupakan konsentrasi berbagai jenis ikan dan biota laut lainnya dalam jumlah kelimpahan yang besar.

Keberadaan ekosistem yang kompleks, pola aliran arus pasang surut yang dinamis, gelombang dan aliran sungai ke laut maupun berbagai aktivitas di kawasan ini mempunyai pengaruh terhadap fosfat, nitrat dan oksigen terlarut. Fosfat dan nitrat merupakan zat hara yang penting bagi pertumbuhan dan metabolisme fitoplankton yang merupakan indikator untuk mengevaluasi kualitas dan tingkat kesuburan perairan (Ferianita-Fachrul et. al., 2005). Namun bila kedua zat ini kosentrasinya sangat besar di perairan dan melebihi nilai ambang batas maka terjadi eutrofikasi (pengayaan zat hara) yang ditandai dengan terjadinya blooming fitoplankton menyebabkan kematian berbagai jenis biota laut. Sumber utama fosfat dan nitrat berasal dari perairan itu sendiri yaitu melalui proses-proses penguraian pelapukan ataupun dekomposisi tumbuh-tumbuhan dan sisa-sisa organisme mati. Selain itu juga tergantung pada keadaan sekeliling diantaranya sumbangan dari daratan melalui aliran sungai yang terdiri dari berbagai limbah industri yang mengandung senyawa organik, mengalami proses penguraian menjadi senyawa anorganik masuk ke perairan dan dalam proses penguraiannya banyak membutuhkan oksigen (Simanjuntak, 2012). Menurunnya kadar oksigen terlarut di perairan menyebabkan terganggunya ekosistem perairan dan mengakibatkan semakin berkurangnya populasi biota. Sumber utama oksigen dalam air berasal dari difusi udara dan hasil fotosintesis organisme berklorofil yang hidup dalam suatu perairan dan dibutuhkan oleh organisme untuk mengoksidasi zat hara yang masuk kedalam tubuhnya (Nybakken, 1988). Kecepatan difusi oksigen dari udara ke dalam air berlangsung sangat lambat, oleh sebab itu fitoplankton merupakan sumber utama penyediaan oksigen terlarut dalam perairan (Suswanto dalam Edward dan Pulumahuny, 2003).

Fosfat, nitrat dan oksigen terlarut merupakan tiga unsur senyawa kimia yang sangat penting untuk mendukung kehidupan organisme dalam suatu perairan. Fosfat dan nitrat dibutuhkan dalam proses dan perkembangan hidup organisme seperti fitoplankton, sedangkan oksigen terlarut digunakan oleh organisme perairan dalam proses respirasi dan penguraian zat-zat organik oleh mikro-organisme. Secara alami ketiga senyawa kimia ini terdapat dalam air laut pada kadar yang sesuai, perubahan kadar yang terjadi tentu akan mempengaruhi kehidupan organisme yang hidup dalam perairan. Dalam tulisan ini akan dikaji tentang sebaran fosfat, nitrat dan oksigen terlarut serta faktor-faktor yang mempengaruhinya di perairan Bolaang Mongondow, Sulawesi Utara.

\section{Metode Penelitian}

\subsection{Waktu dan tempat penelitian}

Penelitian dilakukan di perairan Bolaang Mongondow, Sulawesi Utara pada bulan Pebruari 2019. Penentuan posisi masing-masing stasiun penelitian dilakukan dengan menggunakan handportable GPS (Geographical Positioning System) dan disajikan dalam Gambar 1. 


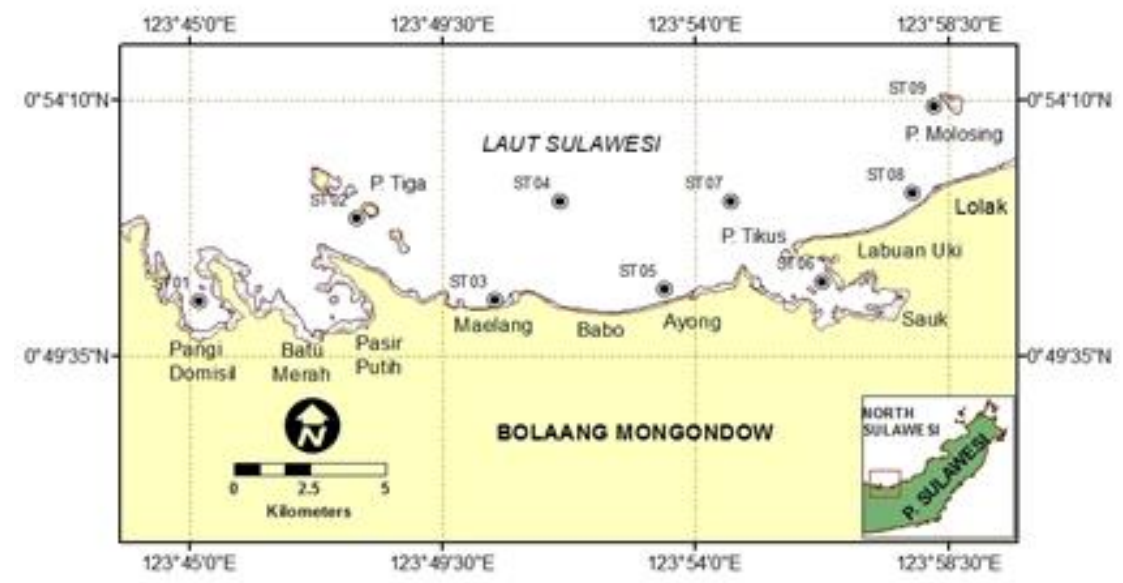

Gambar 1. Peta Stasiun Penelitian.

\subsection{Pengambilan data perairan}

Sampel air laut diambil dengan menggunakan tabung nansen pada lapisan permukaan dan dekat dasar. Analisa fosfat dan nitrat berdasarkan metode spektrofotometri menggunakan spektrofotometer 'UV-Vis' Shimadzu 1700, nilainya dinyatakan dalam mg/l. Semua metode analisis berdasarkan pada buku Standards Methods for The Examination of Water and Wastewater (APHA, AWWA, WEF, 2005). Kadar oksigen terlarut ditentukan dengan metoda elektrokimia menggunakan alat DO meter AZ 8563 dan nilainya dinyatakan dalam ppm. Data diolah dan disajikan dalam bentuk peta sebaran dengan perangkat lunak ArcGis 10.2 dan SURFER 8, serta analisa statistik dengan menggunakan SPSS 16.

\section{Hasil dan Pembahasan}

Hasil pengukuran fosfat, nitrat dan oksigen terlarut di perairan Bolaang Mongondow (Tabel 1) dan hasil anaisa uji-t (Tabel 2).

Tabel 1. Hasil statistik deskriptif fosfat, nitrat dan oksigen terlarut di perairan Bolaang Mongondow.

\begin{tabular}{l|r|r|r|r|r|r}
\hline \multirow{2}{*}{ Kosentrasi } & \multicolumn{2}{|c|}{$\mathrm{PO} 4(\mathrm{mg} / \mathrm{l})$} & \multicolumn{2}{c|}{$\mathrm{NO} 3(\mathrm{mg} / \mathrm{l})$} & \multicolumn{2}{c}{$\mathrm{DO}(\mathrm{ppm})$} \\
\cline { 2 - 7 } & $\mathrm{P}$ & \multicolumn{1}{c}{$\mathrm{D}$} & $\mathrm{P}$ & $\mathrm{D}$ & $\mathrm{P}$ & $\mathrm{D}$ \\
\hline Minimum & 0.0050 & 0.0050 & 0.0050 & 0.0050 & 4.85 & 4.83 \\
\hline Maksimum & 0.0194 & 0.0230 & 0.0080 & 0.0090 & 6.41 & 6.39 \\
\hline Rata-rata & 0.0091 & 0.0104 & 0.0065 & 0.0069 & 5.89 & 5.80 \\
\hline Stand. Deviasi & 0.0041 & 0.0050 & 0.0011 & 0.0013 & 0.59 & 0.60 \\
\hline Koef. Variasi & 44.67 & 47.41 & 16.66 & 19.05 & 9.94 & 10.27 \\
\hline
\end{tabular}

Keterangan: $\mathrm{P}=$ Permukaan

$$
\mathrm{D}=\text { Dasar }
$$




\subsection{Fosfat}

Kadar fosfat lapisan permukaan dan dekat dasar yang diperoleh di perairan ini menunjukkan perbedaan yang signifikan. Kadar fosfat lapisan permukaan berkisar antara 0,005-0,0194 mg/l, dengan nilai rata-rata 0,0091 $\pm 0,0041 \mathrm{mg} / \mathrm{l}$, sedangkan kadar fosfat di dekat dasar berkisar antara 0,005-0,0230 mg/l, dengan nilai rata-rata 0,0104 $\pm 0,0050 \mathrm{mg} / \mathrm{l}$. Konsentrasi fosfat di dekat dasar perairan lebih tinggi dibanding dengan di lapisan permukaan, hal ini disebabkan karena dasar perairan umumnya kaya akan zat hara, baik yang berasal dari dekomposisi sedimen maupun senyawa-senyawa organik yang berasal dari jasad flora dan fauna yang mati (Edward dan Tarigan, 2003). Sedangkan rendahnya kadar fosfat di lapisan permukaan mungkin dapat pula disebabkan oleh aktifitas fitoplankton yang intensif. Fenomena ini diperkuat oleh hasil analisis statistik dengan menggunakan uji-t yang menunjukkan bahwa terdapat perbedaan sangat nyata (t-hit > t-tab) antara kadar fosfat di lapisan permukaan dengan fosfat di dekat dasar (Tabel 2).

Tabel 2. Analisis uji-t terhadap fosfat, nitrat dan oksigen terlarut.

\begin{tabular}{l|c|c|c|c|c}
\hline \multirow{2}{*}{ Parameter } & \multirow{2}{*}{$\begin{array}{c}\text { Sig. (2- } \\
\text { tailed) }\end{array}$} & \multirow{2}{*}{ t-hit } & \multirow{2}{*}{ df } & \multicolumn{2}{|c}{ t-tab } \\
\cline { 5 - 7 } & & & $5 \%$ & $1 \%$ \\
\hline Fosfat permukaan-dekat dasar & 0,009 & $3,459^{*}$ & 8 & 2,306 & 3,355 \\
\hline Nitrat permukaan-dekat dasar & 0,173 & 1,496 & 8 & 2,306 & 3,355 \\
\hline Oksigen permukaan-dekat dasar & 0,006 & $3,699^{* *}$ & 8 & 2,306 & 3,355 \\
\hline
\end{tabular}

Keterangan: * berbeda nyata, ** berbeda sangat nyata

Kosentrasi fosfat dengan kadar terendah mendomonasi perairan menuju ke arah laut, sedangkan fosfat dengan kadar tertinggi sebarannya mendekat ke arah pantai (Gambar 2). Kondisi ini sesuai dengan pendapat Muchtar dan Simanjuntak, 2008 bahwa secara alamiah fosfat terdistribusi mulai dari permukaan sampai dasar, semakin ke dasar semakin tinggi konsentrasinya sebagai akibat dari dasar laut yang kaya akan nutrisi dan konsentrasinya semakin rendah semakin jauh ke arah laut. Kasentrasi fosfat terendah dijumpai di stasiun 04 dan fosfat tertinggi terdapat pada stasiun 06 (dalam teluk). Konsentrasi fosfat yang tinggi ini mungkin disebabkan tingginya difusi fosfat dari sedimen. Sedimen merupakan tempat penyimpanan utama fosfor dalam siklus yang terjadi di laut, umumnya dalam bentuk partikulat yang berikatan dengan senyawa hidroksida dan oksida besi. Senyawa fosfor yang terikat di sedimen dapat mengalami dekomposisi dengan bantuan bakteri maupun melalui proses abiotik menghasilkan senyawa fosfat terlarut yang dapat mengalami difusi kembali ke kolom air (Paytan dan McLaughlin, 2007). Fenomena ini dapat dipahami dengan melihat proses-proses yang terlibat di sekitar permukaan dasar perairan, karena stasiun 06 berada pada perairan semi tertutup dan terisolasi dari perairan lepas pantai sehingga sirkulasi airnya kurang baik. Selain itu juga didukung oleh berbagai aktivitas perkenomian masyarakat di dalam teluk Labuan Uki seperti perikanan, transportasi laut, galangan kapal dan sebagainya, bisa dipastikan bahwa sumber utama penyumbang fosfat ke dalam teluk adalah limbah domestik masyarakat. Menurut WHO \& European Commision (2002) pengkayaan fosfor terutama berasal dari limbah rumah tangga dan industri, termasuk detergen berbahan dasar fosfor. 

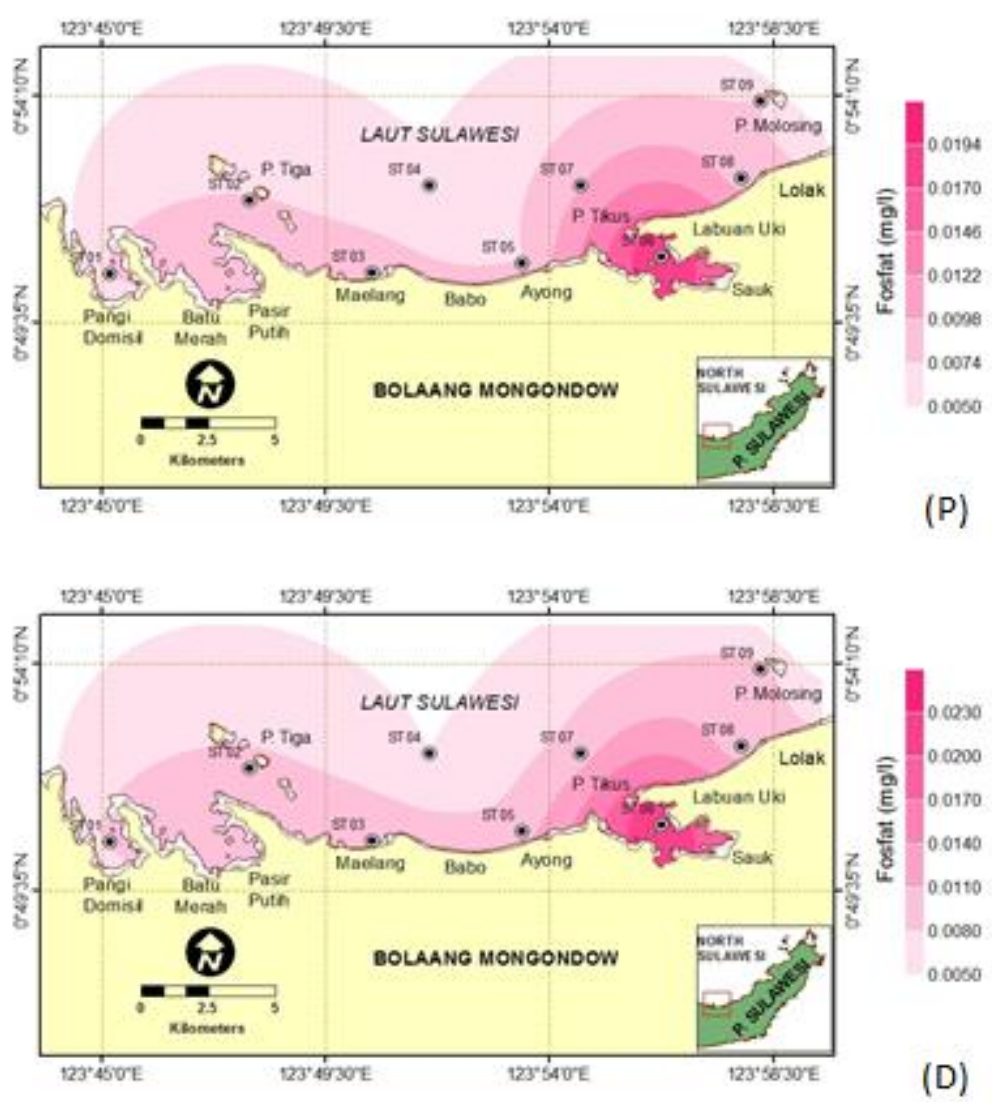

Gambar 2. Distribusi fosfat lapisan permukaan (P) dan dekat dasar (D) di perairan Bolaang Mongondow.

Kisaran nilai fosfat $0,005-0,023 \mathrm{mg} / 1$ menunjukkan bahwa perairan ini cukup subur (Joshimura dalam Wardoyo, 1982) dan sesuai dengan kadar fosfat yang dijumpai di perairan laut yang normal umumnya. Kadar fosfat di perairan laut yang normal berkisar antara 0,01-4 $\mu \mathrm{g}$.at/l atau setara dengan 0,00031-0,124 mg/l (Brotowidjoyo dalam Edward dan Tarigan, 2003). Kadar fosfat di perairan Bolaang Mongondow masih berada dibatasan konsentrasi yang dipersyaratkan, disebutkan bahwa baku mutu konsentrasi fosfat yang layak untuk kehidupan biota laut adalah 0,015 mg/l (Keputusan Menteri Lingkungan Hidup, KLH (2004). Ketchum (1969) menetapkan suatu nilai fosfat sebesar 2,8 ug.at/l atau setara dengan 0,087 $\mathrm{mg} / \mathrm{l}$ sebagai batas atas pada air yang tidak tercemar.

\subsection{Nitrat}

Kadar nitrat lapisan permukaan berkisar antara 0,0050-0,0090 $\mathrm{mg} / \mathrm{l}$ dengan nilai ratarata $0,0065 \pm 0,0011 \mathrm{mg} / \mathrm{l}$ dan dekat dasar berkisar antara 0,0050-0,0090 $\mathrm{mg} / \mathrm{l}$ dengan nilai rata-rata $0,0069 \pm 0,0013 \mathrm{mg} / \mathrm{l}$. Kisaran nilai ini masih di bawah ambang batas, Environmental Protection Agency (EPA), 2002 menetapkan nilai ambang batas untuk nitrat adalah 0,07 $\mathrm{mg} / \mathrm{l}$. Dari data tersebut terlihat bahwa kosentrasi nitrat permukaan dan dekat dasar berbeda, dimana rata-rata kadar nitrat di lapisan permukaan lebih rendah dibandingkan dekat dasar. Rendahnya kadar nitrat di lapisan permukaan karena di lapisan permukaan nitrat lebih banyak dimanfaatkan oleh fitoplankton. Selain itu, konsentrasi nitrat yang lebih tinggi di dekat dasar perairan juga dipengaruhi oleh sedimen. Di dalam sedimen nitrat diproduksi dari 
biodegradasi bahan-bahan organik menjadi ammonia yang selanjutnya dioksidasi menjadi nitrat (Seitzinger, 1988).

Secara umum tidak ada perbedaan yang nyata antara kadar nitrat di lapisan permukaan dengan kadar nitrat di dekat dasar ( $\mathrm{t}$-hit $<\mathrm{t}$-tab). Adanya kadar nitrat yang rendah dan tinggi pada kondisi tertentu dapat disebabkan oleh berbagai faktor, antara lain adanya arus yang membawa nitrat dan kelimpahan fitoplankton. Kosentrasi nitrat terendah dijumpai di stasiun 2 dan tertinggi di stasiun 6. Kosentrasi nitrat permukaan maupun dekat dasar dengan kadar tertinggi sebarannya mendekat ke arah pantai bagian tenggara perairan ini dan kadar terendah penyebarannya menjauh menuju ke arah laut (Gambar 3). Kondisi ini diperkuat oleh pendapat Hutagalung dan Rozak (1997) menyatakan bahwa kadar nitrat semakin tinggi bila kedalaman bertambah, sedangkan untuk sebaran horizontal kadar nitrat semakin tinggi menuju kearah pantai.

Konsentrasi rata-rata nitrat yang diperoleh di perairan ini masih normal dan sesuai dengan kandungan nitrat yang umum dijumpai di perairan laut. Kandungan nitrat yang normal di perairan laut umumnya berkisar antara 0,01-0,50 $\mu \mathrm{g} . \mathrm{at} / \mathrm{l}$ atau setara dengan 0,00014-0,007 mg/l (Brotowidjoyo dalam Edward dan Tarigan, 2003). Bila ditinjau dari kadar nitrat yang merupakan salah satu indikator kesuburan, maka kisaran kadar nitrat di perairan Bolaang Mongondow masih dalam batas aman kesuburan suatu perairan. Disebutkan bahwa baku mutu konsentrasi nitrat yang layak untuk kehidupan biota laut adalah 0,008 mg/l (Keputusan Menteri Lingkungan Hidup, KLH (2004).
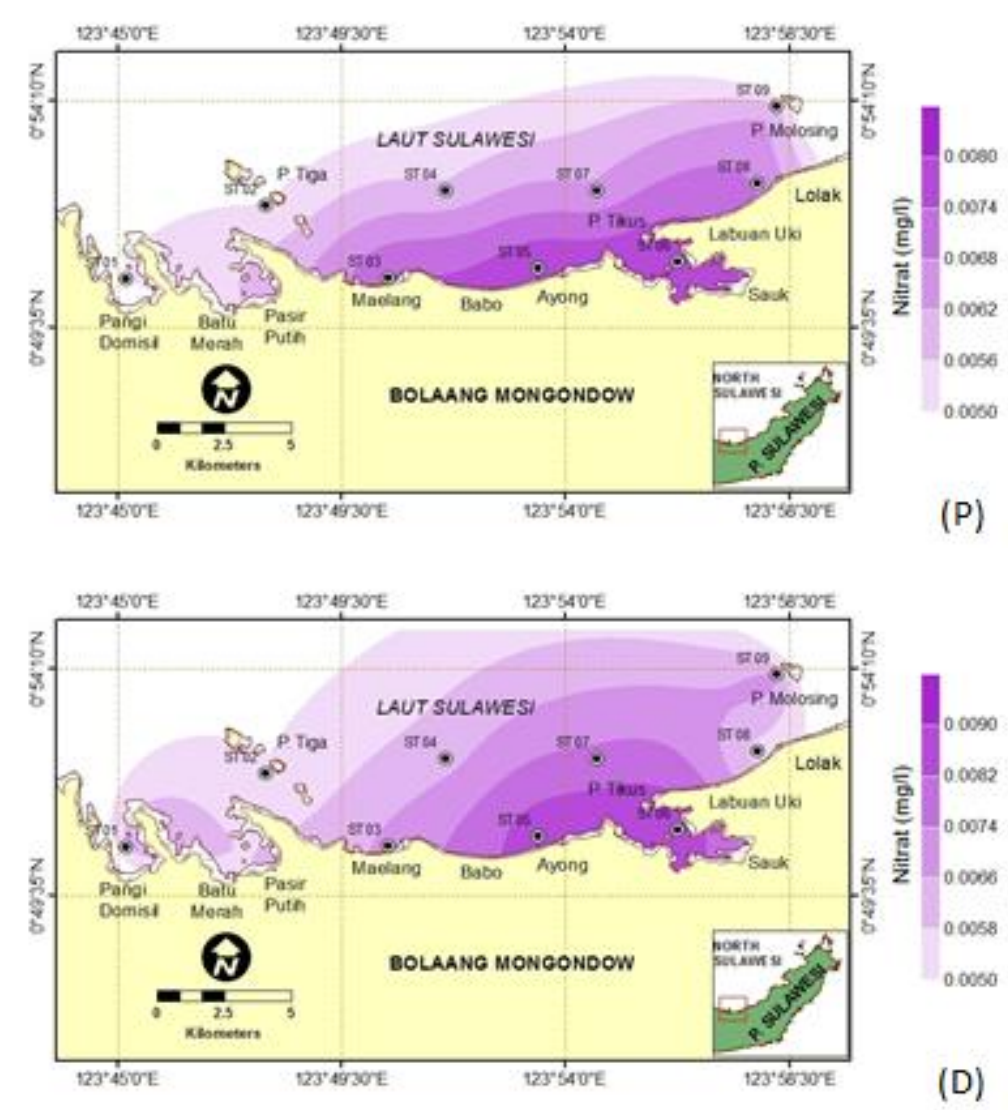

Gambar 3. Distribusi nitrat lapisan permukaan (P) dan dekat dasar (D) di perairan Bolaang Mongondow. 


\subsection{Oksigen Terlarut}

Kadar oksigen terlarut di lapisan permukaan berkisar antara 4,85-6,41 ppm dengan rata-rata 5,89 $\pm 0,59 \mathrm{ppm}$ dan dekat dasar berkisar antara 4,83-6,39 ppm dengan rata-rata $5,80 \pm 0,60 \mathrm{ppm}$. Pada hasil pengamatan terlihat kadar oksigen lapisan permukaan lebih tinggi bila dibandingkan dengan dekat dasar, hal ini disebabkan karena proses pelarutan oksigen yang berasal dari atmosfir terjadi pada lapisan permukaan. Pada lapisan permukaan, kadar oksigen akan lebih tinggi, karena adanya proses difusi antara air dengan udara bebas serta adanya proses fotosintesis (Salmin, 2005). Dengan bertambahnya kedalaman akan terjadi penurunan kadar oksigen terlarut, karena proses fotosintesis semakin berkurang dan kadar oksigen yang ada banyak digunakan untuk pernapasan dan oksidasi bahan-bahan organik dan anorganik.

Hasil analisis statistik dengan menggunakan uji-t menunjukkan bahwa terdapat perbedaan antara kadar oksigen di lapisan permukaan dengan di dekat dasar (t-hit > t-tab). Kosentrasi oksigen lapisan permukaan maupun dekat dasar dengan kadar terendah dijumpai di stasiun 5, sedangkan kadar oksigen teringgi terdapat di stasiun 2 (Gambar 4). Kosentrasi oksigen dengan kadar tertinggi > 6 ppm mendomonasi perairan, sedangkan oksigen dengan kadar terendah sebarannya mendekat ke arah pantai. Rendahnya kadar oksigen terlarut di perairan dekat pantai berkaitan erat dengan tingginya kekeruhan air di lokasi tersebut dan juga mungkin disebabkan oleh semakin meningkatnya aktivitas mikro organisme dalam menguraikan zat organik menjadi zat anorganik yang menggunakan oksigen terlarut. Semakin banyak bahan buangan organik yang ada di dalam air, semakin sedikit sisa kandungan oksigen yang terlarut di dalamnya.
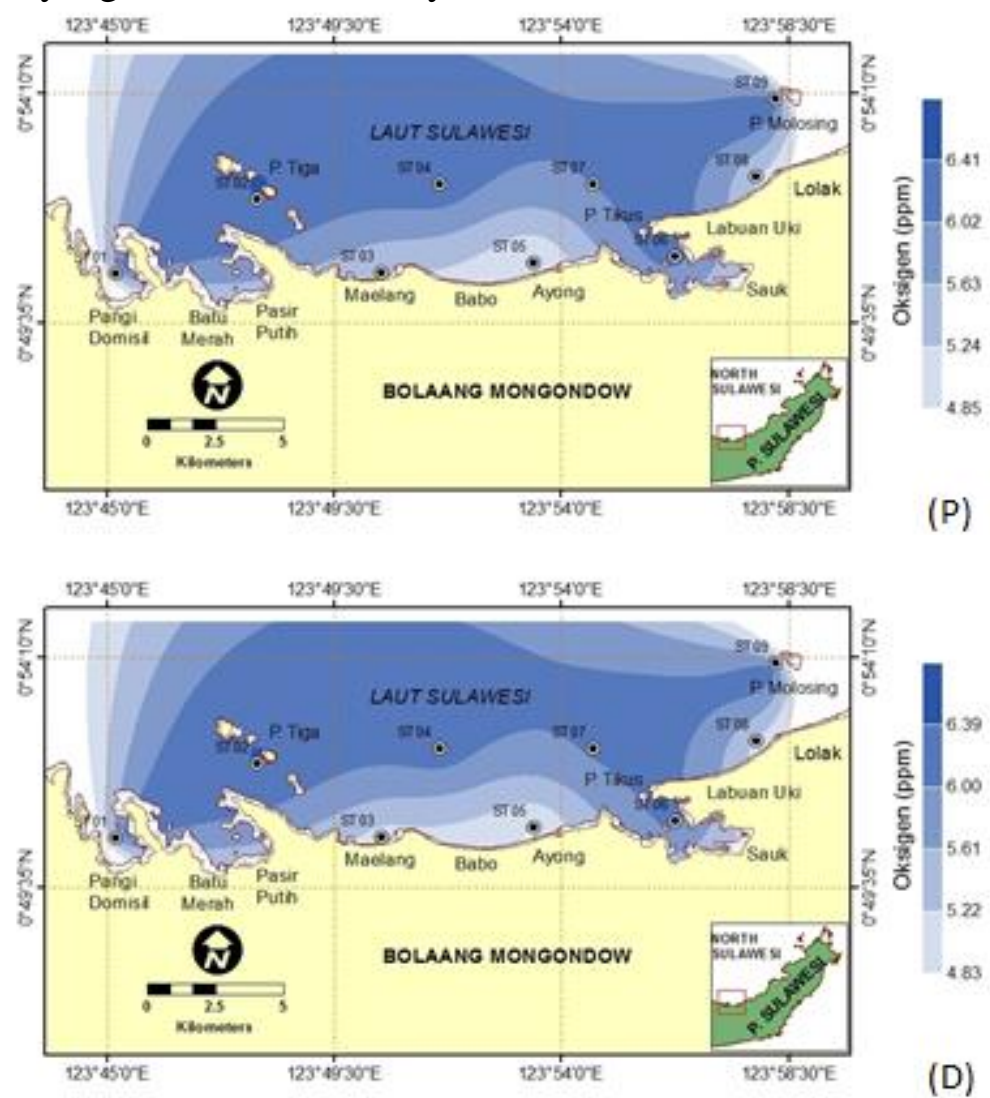
Gambar 4. Distribusi oksigen terlarut lapisan permukaan (P) dan dekat dasar (D) di perairan Bolaang Mongondow.

Konsentrasi rata-rata oksigen terlarut yang diperoleh masih sesuai dengan baku mutu air laut, yaitu $\geq 5 \mathrm{mg} / \mathrm{l}$ (Keputusan Menteri Lingkungan Hidup, KLH, 2004) dan bila dibandingkan dengan kriteria kualitas air, termasuk pada kriteria tercemar ringan 4,5-6,4 mg/1 (Lee, et. al., 1978). Rivai dan Pertagunawan, 1983 mengatakan bahwa pada umumnya kandungan oksigen sebesar $5 \mathrm{mg} / \mathrm{l}$ dengan suhu air berkisar antara $20-30{ }^{\circ} \mathrm{C}$ relatif masih baik, bahkan apabila dalam perairan tidak terdapat senyawa-senyawa yang bersifat toksik (tidak tercemar) kandungan oksigen sebesar 2 ppm sudah cukup untuk mendukung kehidupan organisme perairan (Swingle dalam Salmin, 2005). Kadar oksigen terlarut hasil penelitian ini relatif lebih rendah bila dibandingkan dengan kadar oksigen terlarut di perairan Sulawesi Utara umumnya berkisar antara 3,91-4,46 ml/1 atau 5,59-6,37 mg/l (Simanjuntak, 2006). Kecenderungan menurunnya oksigen terlarut di perairan Bolaang Mongondow sangat dipengaruhi oleh meningkatnya bahan-bahan organik yang masuk ke perairan, disamping faktor-faktor lainnya diantaranya kenaikan suhu, salinitas, respirasi, adanya lapisan di atas permukaan air, senyawa yang mudah teroksidasi dan tekanan atmosfir (Reid, 1961; Welch, 1980 dalam Simanjuntak, 2007).

\section{Kesimpulan}

Kadar fosfat dan oksigen terlarut di perairan Bolaang Mongondow umumnya bervariasi dan berbeda antara lapisan permukaan dengan di dekat dasar, sedangkan kadar nitrat di lapisan permukaan maupun di lapisan dekat dasar perairan relatif sama. Kadar fosfat, nitrat dan oksigen terlarut di perairan ini dipengaruhi oleh arus, pergerakan massa air, aktifitas plankton dan masukkan dari daratan. Bila ditinjau dari zat hara (fosfat, nitrat) dan oksigen terlarut yang merupakan indikator kualitas perairan, maka perairan ini termasuk yang subur, masih dalam kondisi normal untuk kategori perairan pantai dan masih baik untuk kehidupan biota laut.

\section{Daftar Pustaka}

APHA, AWWA, WEF, 2005. Standard method for the examination of water and wastewater, edition $21: 4-153$.

Edward dan F.S. Pulumahuny, 2003. Kadar oksigen terlarut di Perairan Raha, Pulau Muna, Sulawesi Tenggara. Pesisir dan Pantai Indonesia VIII, Puslit Oseanografi-LIPI, Jakarta: 25-31.

Edward dan M.S Tarigan, 2003. Pengaruh MusimTerhadap Fluktuasi Kandungan Fosfat Dan Nitrat Di Laut Banda. Makara Sains, Vol. 7(2): 82-89.

Environmental Protection Agency (EPA), 2002. Water Quality Criteria. Mid-Atlantic Integrated Assessment (MAIA) Estuaries. USA. Ecological Research Series Washington: $595 \mathrm{pp}$.

Ferianita-Fachrul, M., H. Haeruman, dan L.C. Sitepu. 2005. Komunitas Fitoplankton sebagai Bio-Indikator Kualitas Perairan Teluk Jakarta. Seminar Nasional MIPA 2005. FMIPA-Universitas Indonesia, 24-26 November 2005. Jakarta.

Hutagalung, H.P \& A. Rozak. 1997. Metode Analisis air laut, sedimen dan biota. Buku 2. Pusat Penelitian dan Pengembangan Oseanologi LIPI, Jakarta. 
Kementerian Lingkungan Hidup Republik Indonesia (KLH) 2004. Baku mutu air laut untuk biota laut. Keputusan Menteri Negara Lingkungan Hidup No.51 Tahun 2004 Tentang Baku Mutu Air Laut. KLH. Jakarta.

Ketchum, D.H., 1969. Eutrophication of estuaries. In: Eutrophication Causes, Consequences, Corrective National Academy of Sciences, Washington, D.C.: 197-209.

Lee, C.D, S.B. Wang, and C.L. Kuo, 1978. Benthic Macro Invertebrate and Fish as Biological Indicator of Water Quality, With Reference to Community Diversity Index In Onano, E. A. R., B.N. Lohani and Thanh. Water Pollution Control in Developing Countries. The Asian Institute of Technology, Bangkok.

Muchtar, M dan Simanjuntak, 2008, Karakteristik dan Fluktuasi Zat Hara Fosfat, Nitrat dan Derajat Keasaman $(\mathrm{pH})$ di estuary Cisadane pada Musim yang Berbeda, Dalam : kosistem Estuari Cisadane (Editor: Ruyitno, A. Syahailatua, M. Muchtar, Pramudji, Sulistijo dan T. Susana, LIPI: 139-148.

Nybakken, J.W., 1988. Biologi Laut. Suatu Pendekatan Ekologis. Gramedia, Jakarta: 459 hal. Paytan, A.\& K. McLaughlin 2007. The Oceanic Phosphoru s Cycle. Chem. Rev., 107(2): 563576.

Riva'i, R.S. dan Pertagunawan, K., 1983. Biologi Perikanan I, Penerbit CV. Kayago, Jakarta, 143 hal.

Salmin. 2005. Oksigen Terlarut (DO) dan Kebutuhan Oksigen Biologi (BOD) Sebagai Salah Satu Indikator Untuk Menentukan Kualitas Perairan. Oseana, Vol.XXX (3): 21 - 26.

Simanjuntak, M 2006. Kondisi oksigen terlarut dan Apparent Oxygen Utilization di Kawasan Pengelaolaan dan Pengembangan Laut (Kappel) Jawa. Seminar Nasional Kimia dan Kongres Nasional Himpunan Kimia Indonesia. Lembaga Ilmu Pengetahuan Indonesia (LIPI), J1. Jenderal Gatot Subroto No. 10, Jakarta Selatan, 13 hal.

Simanjuntak, M. 2007. Oksigen Terlarut dan Apparent oxygen Utilization di Perairan Teluk Klabat, Pulau Bangka. Dalam : Ilmu Kelautan UNDIP. Vol 12 (2) : 59-66.

Simanjuntak, M. 2012. Kualitas air laut ditinjau dari aspek zat hara, oksigen terlarut dan pH di perairan Banggai, Sulawesi Tengah. Jurnal Ilmu dan Teknologi Kelautan Tropis. Vol.4 (2): 290-303.

Seitzinger, S. P. 1988. Denitrification in freshwater and marine coastal ecosystems : Ecological and geochemical significance. Limnol. Oceanogr. 33(4, Part 2): 702-724.

Wardoyo, S.T.H., 1982. Water Analysis Manual Tropical Aquatic Biology Program. Biotrop, SEAMEO. Bogor. $81 \mathrm{pp}$.

WHO (World Health Organization) \& European Commission. 2002. Eutrophication and Health. Edited by K. Pond. Luxembourg: Office for official Publication of the European communities. $28 \mathrm{pp}$. 